\title{
THE SALT GONTENT OF SOME ICE SAMPLES FROM NORDAUSTLANDET (NORTH EAST LAND), SVALBARD
}

\author{
By Eville Gorham \\ (Freshwater Biological Association, Ambleside)
}

\begin{abstract}
Analyses for $\mathrm{pH}, \mathrm{Na}+, \mathrm{K}+, \mathrm{Ca}^{2}+, \mathrm{Mg}^{2}+, \mathrm{HCO}_{3}-, \mathrm{Cl}-, \mathrm{SO}_{4}{ }^{2-}$ and $\mathrm{NO}_{3}-$ have been made on land ice samples from Nordaustlandet, Svalbard. Total ions range from less than $0 \cdot 02$ to $0 \cdot 46$ milliequivalents per litre, with sea salt generally the dominant component although calcium and magnesium bicarbonates are relatively more abundant in a surface sample heavily contaminated by soil material from an adjacent moraine. These ions, as well as potassium and sulphate, are present in most samples in excess of possible sea-spray supply. From the surface of a crevasse to $14 \mathrm{~m}$. depth down one side the concentrations of all ions except nitrate fluctuate in a similar manner. Some possible implications of the results are examined.

Zusammenfassung. Es wurden Analysen für $\mathrm{pH}, \mathrm{Na}+, \mathrm{K}+, \mathrm{Ca}^{2+}, \mathrm{Mg}^{2+}, \mathrm{HCO}_{3}-, \mathrm{Cl}-, \mathrm{SO}_{4}{ }^{2-}$ and $\mathrm{NO}_{3}$ - an Eisexemplaren von Nordaustlandet. Die Gesamtzahl von Ionen erstreckt sich von weniger als 0,02 bis 0,46 Milliäquivalent pro Liter, wobei Seesalz im allgemeinen den vorherrschenden Bestandteil ausmacht, obwohl Kalzium- und Magnesium-bikarbonat verhältnismässig reichhaltiger in einer Oberflächenprobe, die schwer mit Schuttmassen von einer angrenzenden Moräne verunreinigt ist, vorhanden sind. In den meisten Exemplaren sind von diesen Ionen wie auch von Kalium und Sulfaten mehr vorhanden als durch Sprühregen vom Seeschaum herrührend möglich ist. Von der Oberfläche einer Gletscherspalte bis zu $14 \mathrm{~m}$ Tiefe die eine Seite der Spalte hinunter schwankt die Konzentration aller Ionen mit Ausnahme von Nitrat in ähnlicher Weise. Einige möglichen Folgerungen der Resultate werden geprüft.
\end{abstract}

\section{INTRODUCTION}

During the past few years the study of air and rain chemistry has increased enormously, particularly in Scandinavia (see recent issues of Tellus). However, little is known of the chemical composition of precipitation in polar regions far removed from the major areas of industrial pollution; so that when Mr. Eric Plumpton of the Oxford University Exploration Club kindly offered to arrange collection of samples on their expedition to Nordaustlandet, the opportunity was gratefully taken to obtain a series of "fossil precipitations" from the ice field. These were collected in August 1955 from the "West Ice", near Brageneset and north of Wahlenbergfjorden. It is hoped that the chemical composition of the salts dissolved from the ice may be of interest not only to students of chemical meteorology, but also to persons interested in other aspects of the physico-chemical properties of ice.

\section{SAmpling AND Methods}

The collections consisted of one fresh snowfall, two samples of firn from a site $6 \mathrm{~km}$. inland and $350 \mathrm{~m}$. above sea level, a surface ice sample $3 \mathrm{~m}$. from the edge of a moraine, another surface sample from a crevasse about $\mathrm{I} \mathrm{km}$. from the ice walls and moraines, and a series of samples at $\mathrm{I} \mathrm{m}$. intervals from the surface down to $14 \mathrm{~m}$. depth in another crevasse a similar distance from the sea ice and moraines. Collections were made by exposing a fresh surface and chipping the ice with suitably cleaned metal instruments into a tin box lined with a special paper for each new sample. From this the chippings were transferred to quart polythene bottles and shipped to England for analysis. The analytical methods have been outlined previously, ${ }^{\mathrm{I}}$ but the bicarbonate end-point has been altered to $\mathrm{pH}_{5} \cdot 7$, the value for distilled water in equilibrium with atmospheric carbon dioxide. ${ }^{2}$ Before analysis the waters were filtered through Whatman 54 $\mathrm{I}$ papers, washed with three volumes of distilled water and one volume of sample. Some brownish material was observed in most samples, but this amounted to only a few specks in the samples from deep in the crevasse. In the upper samples there was a good deal more, especially in the sample from near the moraine, which exhibited a thick sediment at the bottom of the bottle. This brownish contamination proved to consist of sandy soil particles embedded in an organic matrix, and obviously derived from the surface of the moraine. 


\section{Results}

The data are presented in Table I (p. I 85), with the individual ions expressed as parts per million and total salt concentration as milli-equivalents per litre. The sums of measured anions and cations balance very closely, which affords a check on the accuracy of the analyses.

Since it is evident that the fresh snow and firn samples are very low in all salts, they need not be considered further here. Of the remaining samples, those near the ice surface are relatively more contaminated by moraine material, and below $3 \mathrm{~m}$. there is very little present. However, apart from slightly higher nitrate levels in the upper samples with more organic contamination, there appear to be no clear correlations of individual ion concentrations with depth.

Among the metal cations sodium is commonly predominant, ranging up to 7.5 p.p.m.; while potassium is on the average least plentiful, and does not exceed 0.6 p.p.m. The maximum concentrations of calcium and magnesium are $\mathrm{I} \cdot 3$ and $\mathrm{I} \cdot \mathrm{O}$ p.p.m. respectively, the former figure coming from the surface sample heavily contaminated by moraine material. Among the anions chloride reaches the highest level, with a maximum of 12.6 p.p.m., and is on the average more abundant than bicarbonate, which amounts at most to 7.8 p.p.m. in the sample near the moraine, but otherwise does not exceed 3.2 p.p.m. Sulphate is in general the least abundant of the major anions, and is near or below the limit of detection in most cases. The maximum concentration observed is 2.8 p.p.m. Nitrate nitrogen was also measured in all samples except the fresh snow and the 5 and $6 \mathrm{~m}$. collections in the crevasse. In the surface samples, and those down to $7 \mathrm{~m}$. depth, the concentrations are in the vicinity of $0.015 \mathrm{p} . \mathrm{p} . \mathrm{m}$., while the deeper samples all give values of o.o Io p.p.m. (The samples were not analysed in order, so that the above difference, though slight, appears to be real.) These nitrate levels are extremely low, and may possibly be explained by disappearance during storage. However, the bottles were stored in a covered box, and no algal growth (the usual cause of nitrate disappearance) was observed.

Acidity in these samples is not high, with the minimum $\mathrm{pH}$ at 5.4 ; but no sample is truly alkaline, although most of the samples are in fact slightly "alkaline" to the $\mathrm{pH}$ of distilled water in equilibrium with atmospheric carbon dioxide. The highest $\mathrm{pH}$ value recorded is $6 \cdot 7$.

\section{Discussion}

The close correlation of sodium and chloride, in much the same proportion to one another as in sea water, indicates that sea spray is an important source of salts; and since the chloride can be assumed to be almost wholly marine in origin, 3,4 the sea spray contribution of other ions can be calculated from their ratios to chloride ions in sea water, assuming all the latter to come from this source. (While it has been conjectured that a separation and differential distribution of sea salts may take place in the atmosphere, ${ }^{5}, 6$ the circumstantial evidence appears open to other interpretations.) The results of such calculations are given in Table II (p. I 86), which includes the sample nearest the moraine as showing the maximum influence of soil contamination, and the average of the crevasse samples below $3 \mathrm{~m}$. depth as being relatively uncontaminated. Data for western Irish 7 and English ${ }^{1}$ rains, and for precipitations at Riksgränsen, the most northerly site in the Swedish air chemistry network (12 monthly samples, December 1954 to December 1955 inclusive, excluding May $1955^{8}$ ), are presented for comparison. As well as the percentage of sea spray contribution, Table II gives the non-marine and total concentrations of individual ions for the various precipitations, all being calculated using the second decimal place, omitted for the sake of clarity from the tables. Owing to the extreme dilution of the samples, the figures for non-marine ions are only to be regarded as rather rough approximations. Since annual precipitation is below $250 \mathrm{~mm}$. in Nordaustlandet, while varying between 1000 and $1500 \mathrm{~mm}$. in the other regions, the supply of atmospheric salts in Nordaustlandet must be regarded as extremely low on an areal basis. 
It is evident from Table II that most of the sodium ( 92 per cent) and a good deal of the magnesium (73 per cent) in the uncontaminated Nordaustland ice derives from sea spray, as is also the case with the other precipitation samples. A moderate proportion of sulphate ( $4^{2}$ per cent) and potassium (3I per cent) also appears to come from sea spray. The precipitation samples from elsewhere give very similar results for potassium, but their marine supplies of sulphate are proportionately lower. The percentage of sea-derived calcium is appreciable (22 per cent) in the deeper Nordaustland ice samples, as in Lake District rain, but the Galway and Riksgränsen precipitations show much lower proportions (6 and 7 per cent respectively), and the moraine-contaminated surface ice receives only about i per cent of its

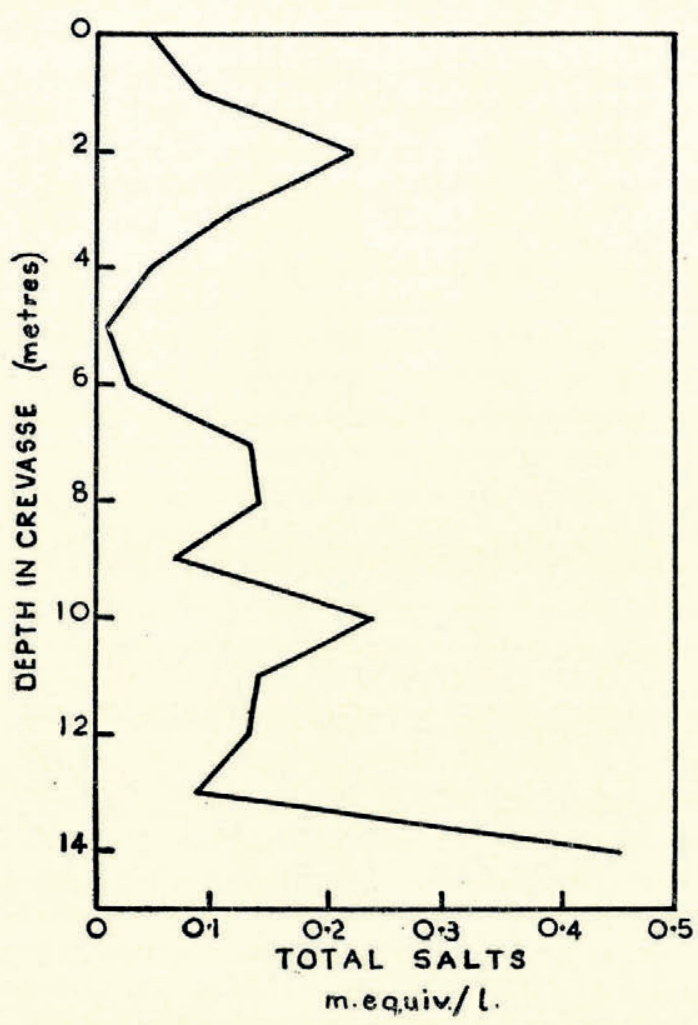

Fig. I. Variation of salt concentration with depth in the ice profile from a crevasse

I. 3 p.p.m. from sea spray. Most of the calcium in all these sites no doubt comes from soil dust, and is balanced chiefly by bicarbonate ions. The high level of non-marine calcium in Galway rain (I.5 p.p.m.) is almost certainly due to dust blown from exposed limestone nearby. Presumably the non-marine supplies of other metal cations also originate as soil dust. The moraine-contaminated ice is very rich in non-marine magnesium (about 0.7 p.p.m.) as compared with the other deeper samples, presumably owing to solution of large amounts of magnesium as well as calcium from the soil particles, which in this area may well be at least partly derived from limestone and dolomite (J. T. Hollin, private communication). Very little sodium, and not much potassium, appears to have been weathered in this way, the nonmarine concentrations being lower than in the deeper ice samples. It may, however, be that the dust contributing to the deeper samples is of quite different composition from the morainic 
material in the heavily contaminated sample, which probably contains some much coarser and relatively unweathered limestone and dolomite particles rich in easily soluble carbonates of calcium and magnesium.

The origin of the sulphate in precipitation is a question of much interest. While in most cases this ion was at or near the limit of detection, a mean figure of about I I $_{\text {p }}$.p.m. appears reasonable for the average of samples below $3 \mathrm{~m}$. depth. It may be reached by assuming all samples with less than the minimum detectable amount to contain half that amount, or by taking the difference between the average concentration of total metal cations (as equivalents) and the sum of the averages for chloride and bicarbonate, and calling that sulphate. It is evident that the level of sulphate in the deep ice series which is not accounted for by sea spray $(0.7$ p.p.m.) is considerably lower than elsewhere, and if the low annual precipitation of Nordaustlandet be taken into account it will be seen that the annual supply per unit area must be very much smaller indeed. Unfortunately, its origin must remain a matter for conjecture. In western Ireland the extensive areas of waterlogged peat may release a good deal of oxidizable hydrogen sulphide gas into the atmosphere, while much of the sulphate of rains in the English Lake District is undoubtedly due to air pollution, ${ }^{\mathrm{I}}$ which is unlikely to be of great significance in Nordaustlandet. However, it must be pointed out that a coal mine at Longyearbyen, nearly $200 \mathrm{~km}$. to the south-west, was set alight in 1943 and has apparently been burning ever since; and the Vestspitsbergen coal mines have been working since the early part of the century; so that fuel combustion cannot be entirely excluded as a possible source of sulphur. A last possible source of atmospheric sulphate is the mud of the continental shelf, which Conway ${ }^{3}$ suggests may supply (as hydrogen sulphide) a large part of the sulphur which cannot be attributed to sea spray. Unfortunately direct measurements of such supply are completely lacking, and the sulphur cycle presents one of the most interesting problems of atmospheric chemistry.

The most striking feature of the crevasse profiles is undoubtedly the marked soil contamination of the upper layers, which is probably due to the ice being formed further inland and pushed down to the sea, where it is exposed at the surface to soil material blown from the adjacent moraines. Evaporation would not seem to be of great importance in this connexion, since salt concentrations are relatively low at the surface and do not run parallel to the degree of soil contamination. Whether the fairly high contamination $\mathrm{I}-3 \mathrm{~m}$. beneath the surface of the ice is general, or due merely to materials blowing against the edges of the crevasse and becoming frozen in, remains to be established. Local upfolding of the ice sheet along its edge may also complicate matters in this respect.

In the heavily contaminated surface ice samples the relation between $\mathrm{pH}$ and bicarbonate is different from that in sub-surface ice. At comparable bicarbonate concentrations $\mathrm{pH}$ is distinctly lower in the surface ice, which may be attributed to the presence of more carbon dioxide, derived presumably from decaying organic material forming the matrix observed to bind the sandy moraine particles together.

Apart from the surface concentration of soil particles, there is a good deal of variability in the distribution of salts in the crevasse profile, as shown in Fig. I (p. 183). A remarkable point about the salt curve is that its main features are duplicated by the curves for individual ions, of which all except that for nitrate show low surface values, a peak at $2 \mathrm{~m}$., then a drop to $5 \mathrm{~m}$., followed by an irregular rise to ro $\mathrm{m}$., another drop, and a sudden rise to maximum concentrations in the deepest horizon at $14 \mathrm{~m}$. Such uniformity of trend among ions of diverse derivation suggests that the variations of salt concentration are more dependent upon changes in the moisture regime than upon variations in salt supply. In this connexion a possibility to be borne in mind is that melting may selectively remove intercrystalline brines before the ice crystals are themselves wholly dissolved, and annual variation in the degree of melting might thus produce variations in salt concentration down an ice profile. (Such a process might also lead to under-estimation of the annual salt supply to the ice surface.) The low surface 
SALT CONTEN'T OF SOME ICE SAMPLES

I 85




Table II. Total and Non-Marine Ionic Concentrations, and the Percentage Contribution from Sea Spray, in Precipitations from Four Different Areas

\begin{tabular}{|c|c|c|c|c|c|c|c|c|c|c|}
\hline & & & $\begin{array}{c}\text { Total } \\
\text { Ions } \\
\text { m. equiv. } \\
\text { per litre }\end{array}$ & $\mathcal{N a}$ & $\kappa$ & $\begin{array}{r}C a \\
\text { parts pe }\end{array}$ & $\begin{array}{r}\mathrm{Mg} \\
\text { million] }\end{array}$ & $\mathrm{HCO}_{3}$ & $\mathrm{Cl}$ & $\mathrm{SO}_{4}$ \\
\hline \multicolumn{11}{|l|}{ Absolute concentrations } \\
\hline Nordaustlandet, near moraine & & .. & $0 \cdot 15$ & 0.3 & $0 \cdot 1$ & I. 3 & $0 \cdot 7$ & $7 \cdot 8$ & $c .0 \cdot 5$ & $<0.5$ \\
\hline Nordaustlandet, below $3 \mathrm{~m}$. dep & & .. & $0 \cdot 14$ & $2 \cdot \mathrm{I}$ & $0 \cdot 2$ & 0.3 & $0 \cdot 3$ & $\mathrm{I} \cdot \mathrm{I}$ & $3 \cdot 4$ & $I \cdot I$ \\
\hline Riksgränsen, northern Sweden & .. & .. & 0.07 & $0 \cdot 9$ & $0 \cdot 1$ & $0 \cdot 4$ & $0 \cdot 1$ & 0.4 & I. 5 & $\mathrm{I} \cdot 2$ \\
\hline \multirow{2}{*}{\multicolumn{10}{|c|}{ Galway, western Ireland, 9 samples excl. }} & $3 \cdot 2$ \\
\hline & & & & & & & & & & $2 \cdot 3$ \\
\hline Non-marine concentrations & & & & \multicolumn{7}{|c|}{ parts per million } \\
\hline Nordaustlandet, near moraine & & .. & & trace & $0 \cdot \mathrm{I}$ & $\mathrm{I} \cdot 2$ & $0 \cdot 7$ & $7 \cdot 8$ & & ? \\
\hline Nordaustlandet, below $3 \mathrm{~m}$. def & & .. & & $0 \cdot 2$ & 0.2 & 0.3 & $0 \cdot{ }_{1}^{1}$ & $I \cdot I$ & & 0.7 \\
\hline Riksgränsen & ... & .. & & 0.1 & $0 \cdot \overline{1}$ & 0.4 & trace & 0.4 & & $I \cdot O$ \\
\hline English Lake District & .. & .. & & 0.1 & $0 \cdot 1$ & 0.2 & nil & absent & & $2 \cdot 7$ \\
\hline Galway $\quad \ldots \quad \ldots$ & .. & . & & $0 \cdot 3$ & 0.2 & I. 5 & 0.2 & $4 \cdot 2$ & & I. 7 \\
\hline \multicolumn{4}{|l|}{ Percentage of sea spray derivation } & \multicolumn{7}{|c|}{ per cent } \\
\hline Nordaustlandet, near moraine & .. & .. & & & 7 & I & 4 & $<\mathrm{I}$ & & ? \\
\hline Nordaustlandet, below $3 \mathrm{~m}$. & .. & .. & & 92 & $3^{\mathrm{I}}$ & 22 & 73 & 2 & & $4^{2}$ \\
\hline Riksgränsen $\quad:$. & .. & .. & & 90 & 25 & 7 & 83 & & & 16 \\
\hline English Lake District & .. & .. & & 95 & 37 & 24 & 100 & absent & & 14 \\
\hline 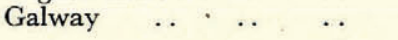 & .. & .. & & 89 & $3^{1}$ & 6 & 67 & $<\mathrm{I}$ & & 27 \\
\hline
\end{tabular}

salt concentrations indicate that the dust-laden winds from the nearby coastal moraines, responsible for the high soil contamination of the surface ice, are not the chief agents of salt supply, otherwise one would expect salt concentration to parallel soil contamination. Presumably the major dust storms do not coincide with the periods of atmospheric precipitation and salt supply.

In conclusion, it may be suggested that variations in salt concentration within ice profiles would be worth examining in relation to changes in ice structure and density, also presumably dependent upon climatic conditions.

\section{ACKNOWLEDGEMENT}

I wish to thank Mr. Eric Plumpton and his colleagues of the Oxford University Expedition to Nordaustlandet in I955 for their generous co-operation in arranging and carrying out the collection of ice samples.

\section{MS. received ${ }_{14}$ February 1957}

\section{REFERENCES}

1. Gorham, E. On the acidity and salinity of rain. Geochimica et Cosmochimica Acta, Vol. 7, 1955, p. 23 I-39.

2. Barrett, E., and Brodin, G. The acidity of Scandinavian precipitation. Tellus, Vol. 7, 1955, p. $251-57$.

3. Conway, E. J. Mean geochemical data in relation to oceanic evolution. Proceedings of the Royal Irish Academy, Ser. B, Vol. 48 , 1942, p. 1 i $9-60$.

4. Eriksson, E. Air borne salts and the chemical composition of river waters. Tellus, Vol. 7, 1955, p. 243-50.

5. Sugawara, K., Oana, S., and Koyama, T. Separation of the components of atmospheric salt and their distribution. Bulletin of the Chemical Society of Japan, Vol. 22, 1949, p. 47-52.

6. Rossby, C.-G., and Egner, H. On the chemical climate and its variation with the atmospheric circulation pattern. Tellus, Vol. 7, i 955, p. I 18-33.

7. Gorham, E. The chemical composition of rain from Rosscahill in County Galway. Irish Naturalists' Journal, Vol. 12, 1957, p. 122-26.

8. Brodin, G. Current data on the chemical composition of precipitation and air. Tellus, Vols. 7-8 (quarterly appendices), $1955-56$. 